\title{
THE DUTY TO BARGAIN COLLECTIVELY
}

\author{
BeNEDICT WOLF*
}

Since the passage of the National Labor Relations Act ${ }^{1}$ there has been a tendency to consider collective bargaining mainly in its legal aspects. Collective bargaining was, even prior to the enactment of the statute, the chief means of an intelligent handling of labor problems and an effective substitute for economic strife. For the past few years, however, public atterition has been directed to the whole subject of collective bargaining, and its importarice has been increasingly emphasized.

Section 8 of the Act states, with reference to collective bargaining:

"It shall be an unfair labor practice for an employer. . . .

(5) To refuse to bargain collectively with the representatives of his employees, subject to the provisions of Section 9 (a)."

Even a cursory examination of the Act as a whole reveals that this subsection really embodies the primary objective of the statute. ${ }^{2}$

The purpose and policy of the statute is set forth in Section I and contains the following language:

"Experience has proved that protection by law of the right of employees to organize and bargain collectively safeguards commerce from injury, impairment, or interruption. . . .

- B.A., 1925, College of the City of New York; M.A., 1928, LL.B., r928, Columbia University. Mem. ber of the New York Bar, practising in the field of labor law in New York City. Secretary of the National Labor Relations Board until November, r937.

49 Stat 449 (r935); 29 U. S. C. (Supp. II) $\$ \$ 15 I-166$.

${ }^{3}$ It is ifteresting to note that this subsection was almost omitted from the Act. The sponsors of the legislation realized the importance of placing upon employers the duty to bargain collectively, but thought that, since $\$ 7$ of the Act gave the employees the right to bargain collectively, there was automatically imposed upon employers 'the duty to bargain. Fortunately, at the hearings before the Senate Committee on Education and Labor, Francis Biddle, then Chairman of the first National Labor Relations Board, urged adding a definite statement making it an unfair labor practice for an cmployer to refuse to bargain collectively. Experience in the administration of $\$ 7(a)$ of the National Industrial Recovery Act had shown the advisability of a clear statement of the duties of employers and the danger of attempting to incorporats into the statute so important an obligation by implication. The Committec on Labor reported the bill to the Senate with Section 8 in its present form. In this connection it is important to note that the United States Circuit Court of Appeals for the Second Circuit in its decision in the case of National Labor Relations Board v. Remington Rand, Inc. on February $x_{4}$, 1938 stated, "We think that strictly a refusal to negotiate is not within Section 8 ( 1 ). The fact that the opposite interpretation would result in an overlap is not indeed conclusive, though redundancy should not be gratuitously ascribed to Congress; but: a refusal to negotiate with one's employees does not properly 'interfere with.' 'restrain' or 'cocree' their right to 'bargain collectively.' Those word's cover affirmative conduct; refusal to bargain is negative and was apparently left to Section 8 (5)." 94 F. (2) 862, 869 . 
"It is hereby declared to be the policy of the United States to eliminate the causes of certain substantial obstructions to the free flow of commerce and to mitigate and eliminate these obstructions when they have occurred by encouraging the practice and procedure of collective bargaining and by protecting the exercise by workers of full freedom of association, self-organization, and designation of representatives of their own choosing, for the purpose of negotiating the terms and conditions of. their employment or other mutual aid or protection."

The Act thus undertakes to protect two fundamental rights of employees, the right to self-organization free from interference, restraint, or coercion by employers, and the right to bargain collectively. Although the wording of the statute might give that impression, these are not really two parallel rights, each of equal importance. Self-organization is not an end in itself but is rather a means to the end of collective bargaining. The primary purpose of the self-organization is to permit employees to become strong enough to conduct collective bargaining through their representatives in an effective manner. If the National Labor Relations Act had been designed to protect only the right to self-organization, employees who organized into labor unions in the exercise of this right would have been able to secure the advantages to be derived from such organization only by the threat of or actual use of economic force. It was in an effort to substitute the orderly processes of collective bargaining for strikes and other forms of industrial strife that the Act imposed upón employers a definite duty to bargain collectively with the duly chosen representatives of their employees.

A brief review of the mechanics involved in the collective bargaining process "will be helpful to an understanding of the legal requirements of the statute. The employer's duty to bargain collectively with the representative of his employees is made subject to the provisions of Section 9 (a) of the National Labor Relations Act. This provision incorporates into the law the famous "majority rule" which had been set forth both by the National Labor Board ${ }^{3}$ and the first National Labor Relations Board $^{4}$ in their attempts to interpret Section 7 (a) of the National Industrial Recovery Act in a manner which would fulfill its function of encouraging collective bargaining. Section 9 (a) of the present Act does not attempt to prevent individual employees or groups of employees from presenting grievances to their employer, and in fact specifically reserves, to them this right. It does, however, prevent a minority of the employees from exercising any collective bargaining rights with regard to matters which affect the employees generally, where a majority of the employees have designated representatives for that purpose.

The first duty the National Labor Relations Board must perform with relation to the collective bargaining process is the determination of the proper bargaining unit. In this field the Board is given rather wide latitude, the only standard set by the statute being that the unit must be one which will insure to employees the full benefit of their right to self-organization and to collective bargaining and which will

${ }^{3}$ Denver Tramway Corporation, I N.L.B. 64 (March I, I934).

'Houde Engineering Corporation, I (first) N.L.R.B. 35 (Aug. 30, 1934). 
otherwise effectuate the policies of the Act. The unit may be either an employer unit, a craft unit, a plant unit, or a subdivision of a plant unit.

Whenever a question arises concerning representation of employees, the Board may investigate and, after a hearing, may certify the representative designated or selected by the employees. It is during the course of such an investigation that the question of unit is determined. The statute makes it mandatory for the Board to provide for an appropriate hearing in representation cases, but the parties may waive their rights in this regard, in which event the Board would probably certify without the formality of a hearing. A certification by the Board may be made either on the basis of proof submitted at a hearing or on the basis of an election by secret ballot. Where certification is based upon proof submitted at the hearing, whether in the form of petitions, authorizations, application cards, or membership cards in the union, the Board requires that an absolute majority of all employees eligible to express their choice in the particular unit involved must have designated the person or organization claiming the right to represent the employees before such person or organization is entitled to certification. Where certification by the Board is based on an election by secret ballot, the designation of a particular representative by a majority of the employees voting in the election is sufficient to secure a certification by the Board, even though the number of employees thus designating the representative may be less than a majority of all the eligible employees in the unit and even though less than a majority of such eligible employees have participated in the election.

Certification by the National Labor Relations Board is not a condition precedent to the duty to bargain. It is true that where the employer has an honest doubt about the propriety of the unit claimed by the union representing the employees he does not have to bargain with the union until the question is resolved by the Board. Similarly, a real doubt that the union has been chosen as the representative of the employees would excuse an employer from bargaining until some authoritative finding of the union's right to represent the employees was made. But the doubt, in each case, must be real. In this connection the United States Circuit Court of Appeals for the Second Circuit stated: ${ }^{6}$

"The respondent answers that it had no official or conclusive information that the Joint Board was the duly accredited bargaining representative of the men, and that it could not have had until the Labor Board had itself so decided. The Labor Board does indeed have that power, Section $9(\mathrm{c})$, and when there is a real doubt, we may assume arguendo that the employer need not decide the issue at his peril; faced by two sets of putative representatives, each claiming to be the properly accredited one, it would seem fairly plain that he need not choose at his peril, especially if he is not allowed to take a vote himself.

"R. C. A. Manufacturing Co., Inc., 2 N.L.R.B. I68 (1936). ("N.L.R.B." citations refer to the volumes of decisions issued by the present National Labor Relations Board In those cases where the decisions have been bound into volumes, the page number is given. In the case of decisions which have been printed but not yet bound, the number of the volume in which the decision will eventually appear and the number of the case are given.)

- National Labor Relations Board v. Remington Rand, Inc., supra note 2, at 868. 
"The same is equally true, though only one set makes the claim; he may readily be in genuine doubt how many it represents. If he cannot satisfy himself of their credentials, and if he cannot by informal appeal to the Labor Board invoke its power, it would certainly seem that he should be free not to recognize either; but from that immunity it does not in the least follow that he need be satisfied with no evidence except the Board's certificate; it may be entirely apparent from other sources that one set really represents the majority."

It is thus apparent that even though the National Labor Relations Board has not certified a representative of the majority of the employees, the employer is not necessarily relieved from his obligation to bargain collectively. The device of certification need be used only when there is a bona fide doubt on the part of the employer regarding the identity of the representative of the employees. The Board has in many cases based its finding that an employer has refused to bargain collectively on the ground that the employer actually knew who represented the employees, and that his insistence on certification was not made in good faith. ${ }^{7}$

The problem of deciding when a duty to bargain has arisen presents no great difficulty. When the question of the propriety of the unit has been determined, doubt regarding the identity of the representatives of the employees has been resolved, and a demand for collective bargaining has been made by the designated representative, the duty to bargain is clear. Much greater difficulty is presented by the question of what the employer must do to satisfy the requirements of collective bargaining.

There has been no attempt on the part of the National Labor Relations Board to promulgate rules covering every type of case in which the question of collective bargaining is involved. The meaning of the phrase "collective bargaining" is still in the process of definition. However, as a result of the Board's decisions in the various cases which have actually been presented to it, a gradual clarification of the meaning of the phrase is occurring and certain general principles are beginning to take shape. 8

The formulation in general terms of a definition of "collective bargaining" is not a particularly difficult task. The National Labor Relations Board has in effect defined the phrase by its declarations that, in order to fulfill the duty to bargain collectively, an employer is obligated to negotiate in good faith and make reasonable efforts to reach an agreement for a fixed period of time regarding working conditions. ${ }^{8}$ The application of this general test to the various factual situations which arise still presents many problems, but a study of the decisions of the Labor Board dealing with the question of collective bargaining gives a fairly clear idea of the particular activities of employers which have been considered refusals to bargain collectively, and thus

\footnotetext{
${ }^{7}$ International Filter Co., I N.L.R.B. 489 (1936); Harbor Boatbuilding Co., I N.L.R.B. 349 (1936).

${ }^{8}$ Both the National Labor Board appointed by the President in August, 1933 and the first National Labor Relations Board appointed pursuant to Pub. Res. No. 44, 73d Cong., 2d Sess. (1934), 48 Srat. Ix83, dealt with this problem and issued decisions with regard to it.

'Atlantic Refining Co., I N.L.R.B.-359 (1936); Edward E. Cox Printer, Inc., I N.L.R.B. 594 (1936).
} 
enables us to learn with some degree of certainty what steps an employer must take to fulfill his duty under Section 8 (5) of the Act.

The employer has no affirmative obligation to institute collective bargaining negotiations, even where he knows that his employees have chosen a representative for that purpose. Where a demand for a meeting has been made by the representative, however, the employer must grant such a meeting. A refusal to meet would almost always be considered a violation of the Act. ${ }^{10}$ It is questionable whether the employer would be permitted to claim at some later date that his refusal to meet the employees' representative was due to his lack of knowledge of the right of that representative to act for his employees. By his own action the employer may have made it impossible for the representative to offer proof that the employees have chosen him as their bargaining agent. In this connection it is interesting to note that the United States Circuit Court of Appeals for the Second Circuit, in the Remington Rand case previously cited, ${ }^{11}$ held that the respondent employer could not excuse a refusal to bargain on the ground that it was in doubt as to the authority of the representative, where the respondent had previously made it clear that its refusal to bargain was not based on any such doubt but rather upon its unwillingness to meet with any representatives who were not its own employees. The Court was of the opinion that, if the doubt had been the real reason for the respondent's refusal to bargain, "presumably it would have been persuaded by the evidence which the Joint Board would have presented. It made no effort to learn the facts and took the chance of what they might be."

Although an employer is not under the duty to take affirmative action with regard to bargaining until a request for bargaining has been made upon him, he is not permitted to deal with persons other than the duly chosen representative of the employees regarding wages, hours, and working conditions, when he knows that ' his employees have already expressed their choice of representatives. Such action on the part of the employer has been held to indicate a desire to avoid or escape the obligation which the law places upon him and has, therefore, been considered a violation of the Act. ${ }^{12}$

Similarly, an attempt by an employer to bargain directly with his individual employees when he knows that they have duly designated a representative for the purpose of collective bargaining would be a violation of Section 8 (5) of the Act.13 The fact that the employer's attempt to bargain with his employees individually occurred during the course of a strike or consisted of an.effort to persuade his $\mathrm{em}$ ployees individually to return to work during the strike does not change the employer's liability in this regard. The National Labor Relations Board, in the

${ }^{10}$ Louis Hornick \& Co., Inc., 2 N.L.R.B. 983 (1937).

"Supra note 2.

- ${ }^{22}$ Shell Oil Co. of California, 2 N.L.R.B. 835 (1937); Elbe File \& Binder Co., Inc., 2 N.L.R.B. 906 (1937).

${ }^{28}$ Hopwood Retinning Co., Inc. and Monarch Retinning Co., Inc., 4 N.L.R.B. No. Ir3 (1938); Atlas Bag \& Burlap Co., Inc., I N.L.R.B. 292 (1936); Timken Silent Automatic Co., I N.L.R.B. 335 (1936). 
Matter of Columbian Enameling \& Stamping Co., ${ }^{14}$ found that, although the respondent was in contact with the representative of the employees, and negotiations had been initiated for the settlement of the strike, the respondent solicited individual employees to return to work, while he refused to engage in actual strike settlement negotiations. These tactics, in the Board's opinion, deprived the employees of a channel through which their return to work as a group could be arranged and in effect "emasculated the Union as an effective instrument of employee representation," and the Board therefore held that the actions of the respondent were unfair labor practices within the meaning of Section 8 (5) of the Act.

The fact that a strike has occurred either before or after collective bargaining began does not relieve an employer of his duty to bargain collectively with the representative of his employees. ${ }^{16}$ In many respects there is a more imperative need for collective bargaining during a strike than there is in the absence of a strike. Even if, as the employer claims, the union has induced the employees to strike by false statements and promises or induced them to engage in acts of violence, this is no excuse for the employer's refusal to bargain collectively. ${ }^{16}$ In response to a defense of this nature, the Board stated that the fact that "bounds of permissible conduct may have been overstepped by men or leaders" during a strike "cannot be used to deny to employees their full right of representation."17

Another reason frequently given by employers for a refusal to bargain collectively is the fact that the employer's competitors have not yet entered into negotiations or made agreements with the union representing their employees. The reaction of an employer who is chosen as the first in the industry or territory to be the recipient of collective bargaining demands is quite understandable and his feeling that he should not be singled out from among his competitors is a natural reaction. It is obvious, however, that to permit an employer to use this as a legal excuse for his refusal to bargain with the union would tend to nullify the statute. If each employer took the position that he would not bargain until all or most of his competitors did, the union representing his employees and the employees of his competitors would be faced with an impossible situation. The Board has therefore held that an employer cannot insist that the union get all of the members of a particular industry or within a particular territory to enter into collective bargaining agreements simultaneously, nor has it excused an employer's refusal to bargain because his competitors have not yet entered into contractual or bargaining relations with the union. ${ }^{18}$

An employer does not have the right to refuse to bargain collectively because he does not like the personalities of the bargaining committee, or because a particular individual on the committee is displeasing to him, or because a member of the com-

16 I N.L.R.B. I8x (1936).

${ }^{25}$ Carlisle Lumber Co., 2 N.L.R.B. 248 (1936); Black Diamond Steamship Corporation, 3 N.L.R.B. No. 8 (1937).

${ }^{16}$ Rabhor Company, Inc., I N.L.R.B. 470 (1936); Consümers' Research, Inc., 2 N.L.R.B. 57 (1935).

${ }^{17}$ Rabhor Company, Inc., supra note 16.

${ }^{18}$ Harbor Boatbuilding Co., 1 N.L.R.B. 349 (1936). 
mittee is not one of his employees. The exclusive right to determine who shall represent them for collective bargaining purposes has been clearly given to the employees, and the employer has no right to limit their powers in this regard.10

In the situations which have just been considered the refusal to bargain collectively was clear, since these situations involved a refusal even to meet with the representatives of the employees. The meeting itself is really only a condition precedent to bargaining. Without it there can be no collective bargaining. A fulfillment of the condition precedent, however, does not mean that there has been a fulfillment by the employer of his obligations under the Act. Even where an employer has met with the representative of his employees, he may take action which in effect nullifies the meeting. Thus the employer may attempt to limit the subject matter of the bargaining in a manner which will actually amount to a refusal to bargain collectively. He may insist that a request for a closed shop must be withdrawn, before he will proceed with the bargaining conference. ${ }^{20}$

An interesting case on this subject was presented when an employer insisted that the adjustment of individual grievances upon request of the representative of the employees relieved him from all further obligation to bargain collectively with regard to wages, hours and working conditions. Employees do not have to choose representatives for collective bargaining in order to exercise their right to present grievances. That right they have at all times and the statute specifically reserves that right to individual employees or groups of employees even when representatives for collective bargaining have been chosen by a majority. The purpose of the choice of representatives is collective bargaining, and bargaining of this nature deals primarily with hours, wages and other basic working conditions. Discussion of grievances and the adjustment of grievances cannot be offered by the employer as a substitute for bargaining with respect to more basic matters, and the refusal by the employer to engage in such bargaining on the ground that he had adjusted grievances was deemed a violation of the National Labor Relations Act."1

As the preliminary steps in the collective bargaining process are completed and the parties come closer to the actual bargaining process, the difficulty in determining whether bargaining is really taking place increases. Where the parties have met and there has been discussion of the demands made by the representative of the employees, the problem of determining whether reasonable efforts have been made to reach an agreement and whether the negotiations have been in good faith must be solved. Obviously, it is necessary to judge each case on the facts involved in that particular case. The determination of the question can only be made after a consideration of the various incidents that have taken place. Admittedly, such determination is often difficult, but it is not impossible. Attempts have been made to show that a statute by the terms of which an administrative agency must apply such

${ }^{10}$ Millfay Manufacturing Company, Inc., 2 N.L.R.B. 919 (1937).

${ }^{20}$ International Filter Co., supra note 7. In this case the enployer argued that mercly mecting with the union representatives would inevitably draw him into a closed shop agreement.

${ }^{21}$ Atlantic Refining Co., I N.L.R.B. 359 (1936). 
standards as "good faith" and "reasonable effort" is unenforceable, but the courts have refused to heed such arguments. In a case before the Supreme Court ${ }^{22}$ the petitioner contended that, if the statute requires the employer to negotiate with the representative of his employees, its obligation was not a proper subject of an equity decree, since equity could not compel the parties to reach an agreement and, since "negotiation depends on desires and mental attitudes which are beyond judicial control," the courts would not compel the employer to negotiate with his employees' representatives. The Supreme Court, answering this contention, stated:

"Whether an obligation has been discharged and whether action taken or omitted is in good faith or reasonable are every day subjects of inquiry by courts in framing and enforcing their decrees."

Thus the legal right of the administrative agency to apply such standards as "reasonable effort" and "good faith" is clear. While this does not lessen the practical difficulty which faces the administrative agencies in their attempts to apply such standards, the National Labor Relations Board has found that certain situations bear clear indications of lack of good faith in the bargaining process.

The representative of the employees who meets with the employer for the purpose of collective bargaining is interested primarily in securing a written agreement, signed by the parties, setting forth working conditions as definitely as possible for a fixed period of time. In order to commence the bargaining process, the representative of the employees will either make certain oral demands or present to the employer a written contract containing the employees' demands. If the employer flatly rejects the proposals submitted by the employees' representative and offers neither counter proposals nor reasons for his rejection, he cannot claim to have made reasonable efforts to reach an agreement and the Labor Board would be likely to find that there has been no collective bargaining in good faith. ${ }^{23}$

A situation like the one just described arose in the case of Matter of the Canton Enameling \& Stamping Co., Inc. ${ }^{24}$ In this case the union presented a proposed agreement to the superintendent of the company. The management decided it would not enter into such an agreement and the superintendent accordingly informed the union that the company could do nothing with regard to the agreement. Thereafter the parties met. The company made no counter proposals, and refused to enter into any agreement with the union, basing its refusal on the ground that there was nothing which the union was requesting in the proposed agreement that the employees did not already have. On this state of facts the National Labor Relations Board, finding that the company's meeting with the union could not in itself be considered collective bargaining, held that the conduct of the company constituted a refusal to bargain in good faith. It is apparent that a flat rejection by an employer

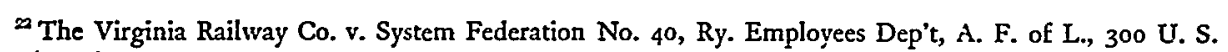
515 (1937).

${ }_{23}$ Edward E. Cox, Printer, Inc., I N.L.R.B. 594 (1936); Pioneer Pearl Button Co., I N.L.R.B. 837 $(1936)$. 
of the union's proposals does not discharge the employer's statutory obligation to bargain. The parties must go through an actual bargaining process, during the course of which an honest attempt to adjust the differences between them must be made. It should be noted that, although discussion by the parties regarding the matters in difference between them may be an indication that bargaining is taking place, such a discussion of working conditions would not in itself be a complete fulfillment of the statutory requiremenț. Discussion will not be accepted as a substitute for negotiation. ${ }^{25}$ In some cases employers have taken the position that they are not required to grant any of the employees' demands but that, if the demands happen to contain suggestions pleasing to them, they may incorporate such suggestions in their employment policies or in statements of working rules and, regulations which are posted on bulletin boards. A refusal by an employer to enter into a definite bilateral agreement even with respect to those demands which he decides to put into effect may be considered a refusal to bargain collectively. ${ }^{26}$

The intention of the employer with regard to the actual consummation of an agreement is important in determining whether collective bargaining has actually taken place. The facts in any particular case may reveal whether the bargaining process was carried on by the employer in good faith or whether he simply went through the motions of meeting and discussing without any intention of ever reaching an agreement. Negotiations, discussions, meetings may extend over a period of months but, if throughout that period the employer had a fixed determination not to enter into any agreement with the representatives of the employees, he has not really bargained at any time during the process described. With respect to such a situation the National Labor Relations Board has stated:

"A construction of the collective bargaining provision which overlooked a requirement that a bona fide attempt to come to terms must be made, would substitute for nonrecognition of the employees' representatives the incentive simply to hamper the Union with needless and profitless 'negotiations.' In the absence of an attempt to bargain in good faith on the employer's part, it is obvious that such 'negotiations' can do nothing to prevent resort to industrial warfare where a dispute of this nature arises."27

A deliberate misrepresentation by an employer of the conditions concerning which bargaining was being attempted has been, in the opinion of the Board, indicative of a determination to nullify the process of collective bargaining and has indicated a lack of good faith on the part of the employer. ${ }^{28}$ Another act which has led to a suspicion of bad faith on the part of the employer has been his insistence that negotiations be carried on through agents who have no authority to enter into collective bargaining agreements and have no instructions with regard to such agreements. Sometimes a trade association will carry on negotiations with a union and, after negotiations have proceeded for a considerable time, the union is informed by

\footnotetext{
${ }^{25}$ St. Joseph Stock Yards Co., 2 N.L.R.B. 39 (r936).

${ }^{20}$ The Timken Silent Automatic Co., I N.L.R.B. 335 (1936).

${ }^{27}$ S. L. Allen \& Co., Inc., I N.L.R.B. 7I4 (1936).

${ }^{20}$ M. H. Birge \& Sons Co., I N.L.R.B. 73 t (1936).
} 
the trade association that it has no authority to bind its employer members. Such actions may tend to show that the association "acted merely as a blind to give pretense of bona fide negotiations." 29

In some cases employers have based their refusal to accede to the demands of the union on the ground that competitive conditions make it impossible for them to grant any of the demands. The validity of this reason depends, of course, on the facts in the individual case. However, where the only demand made by the representative of the employees was for recognition of the union in preference of employment, and he made no request for any change in hours or increase in wages, the Board decided that the employer's attempt to excuse his refusal to grant this request on the ground of competitive conditions indicated a lack of good faith. ${ }^{30}$

From the decisions of the National Labor Relations Board with regard to collective bargaining, we acquire a fairly clear idea of the statutory requirements of the Act. We know that, as a preliminary matter, the Board will undertake to determine the identity of the employees' representative in a proper unit where the employer has an honest doubt concerning the authority of the particular person or organization who claims to represent his employees. We have seen that the employer has no right to refuse to meet with the representatives of the employees because he objects to the personalities of any of these representatives. Once the employees have chosen their representatives and these representatives have requested a collective bargaining conference, the employer's duty to participate in such a conference is clear. We know that when such a conference takes place the employer must listen to the demands presented to him and must make reasonable efforts to reach an agreement with regard to the subject matter of these demands. This effort to reach an agreement must be in good faith and must continue for a reasonable period. The employer must either offer counter proposals or must give reasons for his rejection of the union's demands if he wishes to protect himself against a charge of lack of good faith. Where the terms of a bargain have been reached, they must be incorporated into an agreement, whether written or oral. The employer is not permitted to limit the scope of bargaining negotiations as long as the union demands deal with wages, hours and working conditions. The duty to bargain continues despite the existence of a strike and despite acts of violence on the part of the employees. Even where the employer is freed from his duty to bargain collectively because an impasse in the negotiations has been reached, this duty may, under proper circumstances, be revived.

The principles just set forth are important guideposts to the employer who wishes to fulfill the obligation placed upon him by the National Labor Relations Act with respect to collective bargaining. However, there are still a number of subjects concerning which the Board has not yet clarified the employer's duty. Although it might be foolhardy to attempt to read the future and state with any degree of certainty what the decisions of the Board will be with respect to particular collective bargaining problems which may be brought to its attention, a discussion of some of

\footnotetext{
${ }^{\infty}$ Agwilines, Inc., 2 N.L.R.B. I (1936).

${ }^{30} \mathrm{Tbid}$.
} 
these unsettled problems may enable us to outline trends which are inherent in the past decisions of the Board and thus give some clue to future action.

The National Labor Relations Board has not yet decided whether an employer is under a duty to reduce an agreement to writing where all the terms of the bargain between the employer and the representative of his employees have been agreed upon. There are several cases pending before the Board which have a bearing on this question. The reaction of the first National Labor Relations Board to a situation of this kind is worth noting. In a case ${ }^{31}$ involving this point that Board stated:

"In view of the argument of the Union that a collective agreement, under Section 7 (a), must necessarily be reduced to writing, we desire to state, vithout touching on the applicability of the Statutes of Fraud of the several States, that a collective oral agreement is not necessarily invalid. However, the proposals originally submitted by the Union in this case included detailed provisions covering wages, hours and a variety of working conditions. If an employer assents to most or all of such proposals, the resulting agreement, unless reduced to writing, will be so impractical of enforcement and so fruitful of disputes concerning terms that an insistence by an employer that he will go no further than to enter into an oral agreement may be evidence, in the light of the other circumstances in the case, of a denial of the right of collective bargaining."

The present Board has found that employers have a duty, if an understanding is reached between them and the duly designated representatives of their employees as a result of collective bargaining negotiations, to embody that understanding in a binding agreement for a definite term. ${ }^{3:}$ The basis for such a decision must be that a refusal to embody the terms of an understanding which has been reached into a definite agreement strongly indicates that the employer did not bargain in good faith with the representatives of the employecs. On a similar basis the Board could find that an employer's refusal to transform such an agreement into a written contract was a failure to bargain collectively in good faith. It is difficult to lay down a fixed rule that in all cases a refusal by an employer to enter into a written agreement with the union where the terms of an understanding have been reached would be a violation of Section 8 (5) of the National Labor Relations Act. In some cases the employer's refusal to enter into a written agreement might be so obviously arbitrary as to lead to the inescapable conclusion that the employer was not bargaining in good faith. In other cases there might be some satisfactory reasons excusing the employer's refusal to enter into a written agreement. In general such a refusal would seem to be unreasonable and unlike the conduct which business men employ with regard to their ordinary business dealings. It is very likely that where an employer refuses to reduce to writing the terms of an agreement he has reached with the representatives of his employees the Board would find that there is at least a presumption that the employer was not acting in good faith..$^{32^{a}}$

${ }^{32}$ National Aniline and Chemical Co., I (first) N.L.R.B. II 4 (Oct. 3, I934).

3 St. Joseph Stock Yards Co., 2 N.L.R.B. 39 (1936).

3an Shortly before this article went to press the National Labor Relations Board issued a decision in the case of the Inland Steel Company and Steel Workers' Organizing Committee. Inland Steel Co., No. C-252, April 5, 1938, 2 LABOR ReL. Rep. 180 (1938). In this case the company, at the beginning of 
In the future there will probably be a change in the type of collective bargaining cases which come before the National Labor Relations Board. As familiarity with the National Labor Relations Act and with the decisions of the Board increases, there will undoubtedly be a more widespread compliance with the procedural requirements of collective bargaining. There are less likely to be cases in which the employer is charged with a refusal to meet with the representatives of his employees or with a refusal to discuss with them the demands which they present. More and more the cases will involve the question of whether the negotiations which took place were in good faith and whether the employer made an honest effort to reach an agreement with the representatives of his employees.

Assuming that discussion has taken place, one of the chief problems confronting employers will be how long such discussion must continue and at what point the employer will have the right to break off negotiations on the ground that no agreement is possible. This problem has already received some consideration from the Board. There is no doubt that in the course of the bargaining process, after negotiations have continued for a certain period of time, a point may be reached where further negotiations would obviously be futile. This may occur even though both parties are making all reasonable efforts to reach an agreement. Clearly under such circumstances the employer could cease negotiating without violating the law. The Board, in considering such a situation, ${ }^{33}$ stated:

"It seems apparent from the record that the respondent did engage in collective bargaining with Local No. 455 on and prior to June 20, 1935, even though no agreement had been reached by the parties. Despite the fact mentioned previously that the respondent's good faith in some of its earlier dealings with Local No. 455 is questionable, the fact that the respondent offered to enter into an agreement with Local No. 455 on June I, accepting some of its demands, and met frequently with Local No. 455 in the period from June I to 20, 1935, to discuss the proposals and counter-proposals, leads us to believe that the bargaining by the respondent at that time was done in good faith. It is undoubtedly true that an impasse had been reached by the parties on June 20, 1935, on the three substantive issues of seniority, union shop and check-off, Local No. 455 being unyielding in its demands concerning these issues, the respondent equally firm in its refusal to recede from

negotiations with the S.W.O.C. flatly refused to enter into any written agreement with the union, no matter what understandings might be reached by the parties. The Board held that there was no distinction between this action and a refusal to embody into a written agreement understandings already reached. It found that the company's underlying reason for its refusal to sign an agreement with the S.W.O.C. was its anxiety to forestall the organization of its employees into the union. In the Board's opinion, there was no reason to treat a refusal to enter into a written agreement any differently from a refusal to enter into an oral agreement. Thus its decision in the St. Joseph Stockyards case, sapra note 32, was applicable here. Holding that the reduction of collective agreements to writing is an integral part of the bargaining process, the Board concluded that there is as much of a duty upon the respondent to reduce collective agreements to writing as there is for it to meet with the union, bargain in good faith and comply with the other conditions of the bargaining procedure. Any other interpretation of $\$ 8(5)$ would, in the Board"s opinion, be contrary to the spirit and purpose of the Act. On these grounds the Board held that the company, by announcing its retusal to enter into a signed agreement, had refused to bargain collectively with the union and had thus engaged in unfair labor practices within the meaning of $\$ 8$ ( 1 ) and (5) of the $A c t$.

30 The Jeffery DeWitt Insulator Co., 1 N.L.R.B. 618 (1936). 
its position. As long as this impasse continued the respondent might have been justified in refusing to meet with the Committee on the basis that no agreement was possible."

While it is true that the existence of an impasse may excuse a refusal to negotiate further at the time the impasse is reached, the employer is not forever after freed from his collective bargaining obligations. New facts may come into existence which have the effect of reviving the employer's duty to bargain collectively. In the case which has just been mentioned, negotiations ceased for a period of about a month, during which time the union remained on strike. Thereafter the union secured the services of conciliators from the State and Federal Departments of Labor and an attempt was made by them to reinstitute negotiations. The employer refused to accept the suggestion of the conciliators that further meetings be held with the union. The Board, in reviewing the case, held that since disinterested third parties, representatives of federal and state agencies, had offered to help in an attempt to break the deadlock existing between the parties and since the strike had by that time been continuing for more than a month, the situation had changed sufficiently to reimpose upon the employer the duty to bargain, and that therefore the employer's refusal to meet further with the union was a violation of the requirements of the Act. The United States Circuit Court of Appeals for the Fourth Circuit, in confirming the order of the Board, stated: ${ }^{34}$

"The company's second contention is that it was not guilty of an unfair labor practice in refusing to bargain with the Union on and after July ${ }_{5}$ for the reason that efforts to bargain with it prior to June 20 had resulted in failure and an impasse in the negotiations had been reached. The answer to this is that nearly a month of "cooling time" had elapsed since the negotiations of June $x_{5}$ to 20 , the status of the controversy had undergone considerable change as a result of the operations of the plant, the striking employees after nearly a month of idleness were doubtless willing to make concessions to compromise the matters in difference and conciliators had arrived upon the scene for the purpose of trying to secure an adjustment. It is true that the Act does not require the parties to agree but merely to negotiate with each other; but it is based upon the idea that negotiations honestly entered into will generally result in the settlement of differences and commands negotiation for that reason. Statistics show the reasonableness of the hope upon which it proceeds."

It seems inevitable, that the employer in breaking off negotiations acts at his peril. Before taking this final step, full consideration should be given to the advisability of offering to submit the disputes upon which agreement cannot be reached to a disinterested third party either for mediation or arbitration.

The most troublesome problem which confronts an employer in the process of collective bargaining is to determine to what extent he must accede to the demands of the union in order to free himself from the suspicion of lack of good faith. Strictly speaking, the duty of an employer to bargain collectively does not necessarily involve' a duty to accede to the demands of his employees, ${ }^{35}$ nor is the fact that he has made

\footnotetext{
3t The Jeffery DeWitt Insulator Co. v. National Labor Relations Board, 91 F. (2d) 134 (1937).

${ }^{35}$ Sands Manufacturing Co., 1 N.L.R.B. 546 (1936).
} 
no counter proposals definite proof of lack of good faith on his part. Where a case is presented to the National Labor Relations Board in which discussions have taken place and negotiations have finally been broken off without any agreement having been reached, the Board will have to make a fairly close examination of the reasons given by the employer for his refusal to accede to demands or to offer some compromise. In such a case the reasonableness of the demands themselves may be a determining factor in the conclusion reached by the Board.

Another factor which will become important in such a case will be the subject matter of the demands. There can be no doubt that the union may properly present demands with regard to matters directly affecting wages, hours and working conditions, and the employer would have no right to refuse to bargain regarding such demands. However, the union might make demands with reference to subjects which the employer could well claim were not properly within the scope of collective bargaining and his refusal to bargain in such a case might be justified. For instance, although the employees have a vital interest in the success of the business enterprise (since on this depends their wages and, in fact, their jobs), it is doubtful whether an employer will be under any duty to bargain with the union regarding the prices he fixes for his products, even though admittedly the prices fixed by the employer have an important effect on the success of the business. Although to salesmen working on a commission basis the amount of advertising done by an employer is undoubtedly important, the chances of an employer being penalized for refusal to bargain with regard to his advertising budget are slim. These matters are primarily management problems and affect working conditions indirectly. There are few things with relation to the conduct of a business which do not have some effect on working conditions and it is difficult to conceive that an employer would be in duty bound to bargain with the representatives of his employees concerning all the details of running his business. The classic concept of management problems as differentiated from working conditions might well be used as the test in the determination of the employer's right to limit the scope of the bargaining process.

An employer is probably under less of a duty to bargain with regard to a change in the terms of a contract already in effect than he is with regard to working conditions where no agreement has previously been reached. It would seem reasonable that, where the parties have entered into an agreement for a definite period of time, the terms of that agreement should remain unchanged until the period has expired, since one of the purposes of the agreement is to secure stabilization of labor costs as well as of working conditions. However, the existence of a contract which is binding upon the parties may not be complete insurance for the employer who refuses even to discuss changes in the contract during its term. The parties to a contract can by mutual consent change the terms during the contract period and, if unusual circumstances arose during that period, the employer might be under a duty to discuss the union's demands with regard to such changes. Even though a refusal to accede to requests for changes in contract terms would not in most cases be deemed a real 
refusal to bargain, it would seem to be advisable for an employer at least to meet with the union and discuss its demands with regard to such changes.

There are certain demands frequently made by a union, the refusal of which casts strong suspicion on the employer's good faith. In this category. fall the demands for rights guaranteed to employees by law. A refusal to grant the union's request for a guarantee against dismissal for union activity might be difficult for an employer to explain. The demand for recognition of the union as the collective bargaining agency of the employees is one whose refusal would indicate that the employer is not acting in good faith. Similarly, the employer's insistence that the union's requests with regard to certain terms of employment, where such terms are satisfactory to the employer, must be transmitted to the employees as the employer's labor policy rather than as an agreement reached with the union is likely to impugn the employer's motives.

The attitude of the employer during the collective bargaining process will play an important part in determining whether he has bargained in good faith. It is true that the law does not require that any particular demands must be granted or that an agreement must be reached, yet an employer who insists at the time he commences a collective bargaining conference that under the law he does not have to reach an agreement or grant any demands is likely to find himself faced with a charge that he made no reasonable efforts to reach an agreement. This may be true even where the employer has determined beforehand that he is actually unable to grant any of the union's requests, for experience has shown that frequently in the course of discussion unions have been able to demonstrate to employers that certain of their requests could be granted without imposing as great a burden on the employers as they had originally thought would be necessary.

The minute details of the manner in which the collective bargaining conference has proceeded may become very important in cases where the employer has refused all of the union's demands and made no counter proposals. The employer who, when he has been presented with the demands of the union, takes the arbitrary position that he cannot grant any of these demands and is unprepared to make any counter proposals, may be acting in good faith, yet his actions may be so unreasonable that there inevitably arises a suspicion of lack of good faith on his part, and a charge of refusal to bargain collectively is made to the National Labor Relations Board. As has already been stated, there is no requirement that an employer must grant all or any of the union's requests or that it is absolutely essential for him to make counter proposals. The employer may find himself unable, because of economic conditions, to change the existing terms of employment but in such a case his attitude at the collective bargaining conference takes on an added importance. For instance, if a union's sole request is for a raise in wages and the employer's answer is a fat refusal, he is likely to be found to have violated the collective bargaining requirements of the National Labor Relations Act even though as a matter of fact the financial condition of his business makes it impossible for him to grant any wage increase. 
On the other hand, if this same employer, upon receipt of the union's request for a raise in wages, sits down with the union representatives, discusses his financial condition in detail with them, perhaps permits them to inspect his books, and then suggests that the discussion regarding a raise in wages be postponed to some future date when his financial condition may be improved, he will most likely be free from any charge of refusal to bargain collectively. True, the result in both cases would have been the same but in the second case the employer would have demonstrated a sincerity and a reasonableness the lack of which in the first case strongly indicated an absence of good faith.

The employer who bases a refusal to discuss with the union its initial demands on the ground that these demands are utterly unreasonable will probably find that such a ground for his refusal lacks validity. It may be assumed that the demands originally presented by a union, although they undoubtedly represent what the employees would like to secure, do not necessarily represent either what they expect or the minimum which they would accept. Whether it is fortunate or unfortunate, the fact remains that the history of bargaining in the field of labor relations as well as in other fields has made those who seek to reach a bargain realize that the need to grant concessions is almost inevitable. As a result, in many instances demands are deliberately exaggerated in order to provide room for such concessions. This applies, of course, with respect to both parties to the bargaining process. When the union asks for a certain wage increase, it may be willing to accept a smaller increase. When the employer insists that he is unable to raise wages, he may be using this as a defense for what he deems are unreasonable demands by the union and may, in fact, be prepared to grant some increase in wages. Eventually, as a result of the bargaining process, a compromise which is satisfactory to both parties may be reached. What has just been stated with regard to wages applies with equal force to hours and other working conditions. There will, of course, be times when the union refuses to recede from any of its original demands or to accept any counter proposals. Such action on the part of the union might well give rise to an inference that the union was not bargaining in good faith, and this circumstance would urdoubtedly be given weight in a determination by the National Labor Relations Board of whether the employer has complied with the requirements of the Act.

Certain matters which are properly the subject of collective bargaining do not lend themselves very easily to compromise. The demand for a closed shop or a check-off are instances of this sort, yet even on such demands satisfactory compromise has resulted where the parties are sincerely desirous of reaching an agreement. Frequently a preferential union shop has been granted by an employer and accepted by a union where the union was at first adamant in its insistence on a closed shop provision in a contract.

As long as there is some hope of reaching an agreement, both parties should be extremely reluctant to break off negotiations, the union because by so doing it may destroy the validity of its charge that the employer has refused to bargain collec- 
tively, ${ }^{36}$ and the employer because of the danger that he will be violating the Act. Even where the successful conclusion of negotiations seems impossible, both parties to the negotiations may be under a duty to secure the help of a neutral third party in the adjustment of their differences before giving up all hope of reaching agreement. Certainly neither party should run the risk of refusing the other's suggestion that outside aid be secured. The employer who has come to the conclusion that further negotiations would be futile and who wishes to be completely protected from a charge that he has not complied with the collective bargaining requirements of the Act is likely to find such complete protection by an offer to submit to arbitration all matters which still remain in dispute.

Without going into a detailed discussion of the question of the responsibility of labor unions, it may be well to point out that the hope of an employer that he can excuse a refusal to bargain on the ground that the union designated by his employees as their representative is not "responsible" is likely to be a vain hope. It is up to the employees to decide whom they want to represent them and, once they have chosen, the employer's duty to bargain with the representative of their choice is fixed. An objection on the ground of lack of responsibility of a union will come with poor grace from the lips of an employer whose strong and vigorous opposition to the organization of his employees may have had much to do with the lack of stability of the union.

It is true that the value of a contract to an employer and the likelihood of the union's abiding by the terms of the contract depend to a considerable extent upon the stability and permanence of the union. Usually the organization which has achieved such stability and permanence is in the best position to assure the employer that the terms of the agreement which are reached as a result of collective bargaining will be observed. The absence of opposition on the part of an employer to the organization of his employees by a union may thus have a direct effect on the likelihood of observance of the terms of the contract which may finally be reached. The type of union leader needed to organize a plant against the vigorous opposition of an employer may not be the type who can most successfully engage in collective bargaining or enforce union discipline to insure observance of the contract. However, where the employer does not oppose the organization of his employees, the type of leadership in the union will probably be stable and responsible, a fact from which the employer will derive direct benefit after a collective bargaining agreement has been reached and the observance of this agreement by the union becomes important to him. Those unions which have the longest history of collective bargaining usually have the best record of observance of contracts.

A discussion of collective bargaining which is limited solely to its legal aspects does not give a complete picture of the subject. Therefore, without attempting any detailed analysis of the labor relations aspects of collective bargaining, I wish to stress certain factors.

\footnotetext{
${ }^{80}$ Seas Shipping Co., Inc., 4 N.L.R.B. No. 88 (1938).
} 
Collective bargaining is more than just a statutory requirement. It is probably the chief substitute for industrial strife and its value in this respect has been demonstrated repeatedly in recent years. The importance of the role collective bargaining plays in the field of labor relations can be seen from the frequency with which matters involving collective bargaining have been brought to the attention of the National Labor Relations Board. The Board handled almost 12,000 cases prior to February I, 1938. In more than 2,500 of these cases the main cause of complaint was based upon the refusal of employers to engage in collective bargaining with the representatives of their employees, while in more than 3,500 cases the Board was requested to determine whom the employees wished to represent them for the purpose of collective bargaining.

The principles established by the Board with regard to the law of collective bargaining are sound principles, even when judged by the standards of labor relations. The employer who refuses to meet with the representatives of his employees is not only violating the law but is disregarding his own best interests. Even where. an employer is convinced that no agreement with his employees is possible, a meeting with the representatives has its own distinct value, for it provides a means whereby the employer may learn what specific matters are irritating his employees. Every employer who seeks efficiency in operation knows how important it is that discontent on the part of his employees be reduced to a minimum. Frequently at such meetings the responsible supervisory officials learn for the first time of the existence of conditions which are extremely irksome to the employees and yet are easy to correct, conditions resulting from actions on the part of subordinate officials which the responsible officers of the employer would not condone. Such things may never come to the attention of these officers except through a meeting with representatives of the employees, particularly when these representatives are not in the company's employ and are therefore free from fear of reprisal on the part of foremen or other minor officials.

In addition, a meeting between the employer and representatives of the employees provides a vehicle by which the employer can convey to the employees a realization of the difficulties confronting management and thus secure a sympathetic understanding of the forces which make it necessary for the employer to maintain working conditions which may be less than perfect but which he may, for various reasons, be unable to correct. Responsible union officials can and frequently do play an important role in bringing to the employees a knowledge of the problems facing management.

Collective bargaining negotiations, wherein both parties are actually seeking to reach an agreement, also have value apart from any statutory considerations. Unless organized employees can make their demands known to the employer through their chosen representative and this representative can then attempt by negotiation to secure from the employer the conditions sought, the employees are likely to conclude that the only way to get what they are seeking is by a strike. It is precisely because 
the process of collective bargaining provides a means by which differences may be ironed out and changes in conditions may be secured peacefully that collective bargaining is so important in the field of labor relations. The use of collective bargaining is no insurance against strikes, but it is an assurance that some attempt will be made to adjust disputes by peaceful means before there is an ultimate application of economic force.

What has been said with regard to the attitude of an employer at a collective bargaining conference is just as important from the viewpoint of industrial relations as it is from the viewpoint of statutory requirements. The employer who is arbitrary or unreasonable at such a conference and as a result causes the employees' representatives to feel that he is not acting in good faith has not only made himself liable to a charge of violation of the National Labor Relations Act but has probably done an effective job of substituting for the spirit of cooperation which may have existed among the employees a spirit of distrust and opposition. Under such circumstances the chances of maintaining harmonious industrial relations are seriously threatened.

The penalty for failure to adhere strictly and whole-heartedly to the requirements of the Act with respect both to the right of employees to organize and the right to bargain collectively is likely to involve much more than the action taken by the National Labor Relations Board or by the courts. Decreased efficiency as a result of the discontent of the employees and their feeling of instability takes its own toll in the form of increased operating costs. From the point of view both of obedience to the law and of the intelligent handling of labor relations problems, the employer who realizes the value of collective bargaining and the aid it gives him in the achievement of the harmonious industrial relations necessary for the efficient operation of a plant will be in a far better position in every respect than the employer who realizes only that the law insists upon collective bargaining and who feels that this legal requirement is an irksome burden. 